\section{Historical light on photography}

SIR- During the historical session of the French Academy of Sciences on 19 August 1839, F. Arago disclosed the now wellknown daguerrotype process invented by Daguerre $^{\prime}$. But a few years earlier, in 1816, Joseph Nicéphore Niépce obtained the first negative picture on a paper coated with silver salts and placed in a crude camera obscura ${ }^{2}$. The picture was sent in a letter to his brother, but it was not fixed, and he also failed to produce a positive from it.

Niépce investigated numerous lightsensitive compounds which he classified into three types with respect to the effect of light: "colouring properties, discolouring properties and solidifying properties". He eventually succeeded in irreversibly fixing on a support the reflection of light from a landscape by using asphalt spread on glass, stone or metal. In 1829 he described his process which was published 10 years later ${ }^{1}$. Niépce had discovered that bitumen hardens on exposure to light, thus making it possible to capture the imprint of light and shadow of an image by removal of the unexposed areas with an appropriate solvent.

But the process, termed heliography by Niépce, remained obscure. Only a unique picture called Point de vue du Gras, obtained by Niépce in 1826, is known and his work cannot easily be evaluated from this single heliograph.

We have attempted to reproduce Niépce's technique and in June 1989 were able to produce the first heliograph ever made since Niépce's time ${ }^{3}$. We followed all his written methods, and experimentally determined the exposure time, which he never mentioned. The heliographic process is, in practice, rather different from the interpretation given by historians and provides a clearer understanding of some of the explanations given by Niépce in his letters.

The photosensitive compound used by Niépce was bitumen of Judea, or asphalt ${ }^{4}$. In Niépce's process, bitumen is dissolved in oil of lavender and spread as a thin layer on a well polished silver-coated plate as a varnish. This constitutes a photosensitive film which, under the action of light, partially loses its properties of solubility due to a crosslinking process 5 . This variation of solubility with dose allows one to dissolve the areas where the varnish remains soluble - those which have not been illuminated - while it becomes insoluble in the exposed areas.

The bitumen we used is a commercial product (Prolabo) in the form of a brown powder. Our preparation of the wellpolished silver plate, covered with the bitumen varnish to obtain a thin golden brown film follows exactly the operations described by Niépce ${ }^{1}$. The optical absorption spectrum of a thin film of bitumen prepared from a bitumen solution $(3 \mathrm{~g}$ in $10 \mathrm{ml}$ of lavender oil) shows an optical density at wavelength's under $500 \mathrm{~nm}$.

In the literature of the history of photography, the formation of an image by the Niépce process is explained as the simultaneous hardening and whitening of the bitumen under the action of light and thus would be a direct positive process ${ }^{2.6-8}$. Our first experiments were performed by irradiating homogeneously the light-sensitive plate either with sunlight or with a
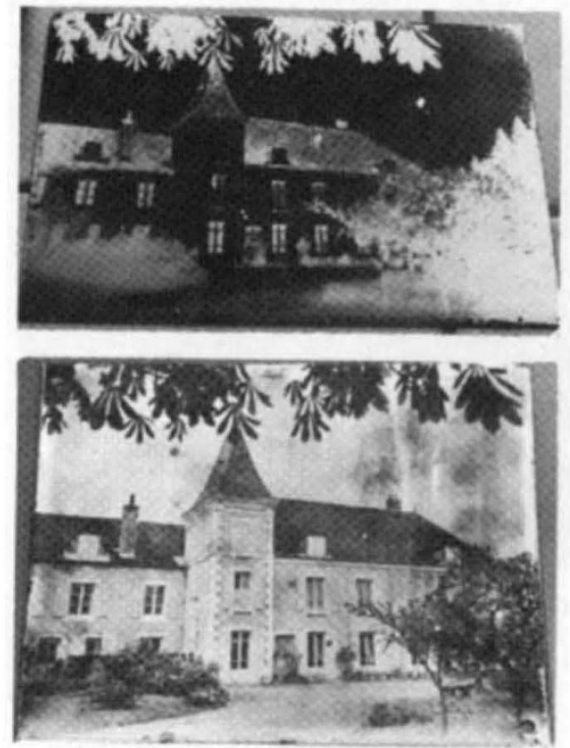

Top: negative image obtained with bitumen of Judea by using contact printing (see text). Light areas correspond to bright silver, dark areas consist of crosslinked brown bitumen. Bottom: direct reaction of iodine vapours on the negative image leads to the formation of silver iodine only where the bright silver of the negative image was apparent. Under the action of light these bright areas turn black. After complete removal of the bitumen still present, the positive image is obtained. (Le Gras: Niépce's house at St Loup de Varennes near Chalon-sur-Saône, France)

halogen lamp whose light intensity was controlled; the bitumen hardened under these conditions. But no change in the golden brown colour was detected even after a long irradiation with visible or ultraviolet light. Niépce said that no colour variation is observable after exposure to light. There is no whitening of the bitumen with light, contrary to what has frequently been claimed ${ }^{1.2 .6-9}$.

Niépce's method of obtaining a positive image is the following: the unprotected bright silver is blackened by submitting the negative plate to iodine vapours. This leads to the formation of silver iodine at the surface of the plate which is then transformed, under daylight, into finely divided black silver. The last operation consists of stripping the hardened bitumen off the plate with alcohol. In its final form, no trace of bitumen is left on a heliograph. The bitumen plays the role of an inter- mediate compound, like a negative image laid on silver. Iodine vapours penetrate the different areas of bitumen, proportional to their density, and restore all the variations of greys from black to white. The shadows are made of black colloidal silver, while the lights are polished silver. The image we obtain has a high resolution (80 lines per $\mathrm{mm}$ ) and good reproduction of shades of grey.

Our second important result concerns the exposure time. Many hypothesis have been suggested ${ }^{2}$ as Niépce never clearly mentioned this parameter. Three different methods have been used to obtain heliographs: (1) by projecting a slide magnified from $24 \times 36 \mathrm{~mm}$ to $80 \times 100$ $\mathrm{mm}$ with a slide projector equipped with a 150-W lamp and a $f$ 2.8-aperture lens (about 55,000 lux on the bitumen). The exposure time ranges from 10 to 15 hours. (2) By. contact printing under the Sun (about 350,000 lux) of a positive modern photograph on a transparent film. The exposure time varied from 1.5 to 3 hours. (3) In a camera with a $f 3.5$ aperture lens (similar to Niépce's method for obtaining heliographs with a camera obscura). In this case, our experiments showed that the level of light on the plate was 5,500-11,000 lux. Therefore an exposure time $60-100$ hours is required. These times are in agreement with those mentioned by Biot in 1839 , who wrote that the Niépce process needed 2 or 3 days under a very intense light to obtain an image from nature in a black box ${ }^{10}$. Thus Niépce could only heliograph static subjects in very intense light. But Niépce's discovery opened the way to his successors.

The exceedingly low sensitivity of bitumen of Judea explains why the different steps of the whole process, such as the preparation of the varnish or its dissolution after exposure, can be carried out under room light without damage. It seems that the determination of the exposure time is the main obstacle preventing the reproduction of Niépce's process. Some historians have eronously concluded that the exposure time was 8 hours for a landscape illuminated by a bright Sun".

J. L. MARIGNIER

Laboratoire de Physico-Chimie des

Rayonnements,

CNRS, UPS Orsay,

91405 Orsay Cedex, France

1. Daguerre, L. Historique et description des procédés du daguérréotype (ed. Giroux, A) (Paris, 1839)

Jay, P. Niepce, genèse d'une invention (Musée Niépce, Chalon-sur-Saöne, 1988

3. Marignier, J. L. Symposium pour les 150 ans de la photographie 29 June-2 July, 1989, Vevey, Switzerland

4. Connan, J. \& Dessort, D. C. R. hebd. Acad. Sci., Paris 308, 1665 (1989)

5. Kosar, J. Light sensitive systems (Wiley and sons, 1965)

6. Hedgecoe, J. \& Bailey, A. Le livre de la photographie (Larousse, Montel, 1976).

Gautrand J. C. Photojournal 1, (Paris, November 1979).

8. Foiret, J. les miroirs qui se souviennent (Syros-Alternatives, Paris, 1987)

9. Potonniee, G. Histoire de la découverte de la photographie. (Paris, 1925)

10. Biot, J. B. J. de. Savants (1839) 